\title{
In the Best Interest of the Child? Justifying Decisions on Adoption from Care in the Norwegian Supreme Court
}

\author{
Hege Stein Helland \\ Centre for Research on Discretion and Paternalism, Department of \\ Administration and Organization Theory, University of Bergen, Christiesgt, \\ Norway \\ hege.helland@uib.no
}

\begin{abstract}
By utilising theories of deliberation and rational argumentation, this article critically analyses the Norwegian Supreme Court's best interest decisions in four judgments on adoption from care. How does the Supreme Court reason their decisions and are the decisions rational? The findings show that the decisions are reasoned similarly, and conclusions are guided by norms of biology, vulnerability and stability for the child. However, discretion is applied differently across decisions, and the reasoning and balancing of individual arguments vary. The critical evaluation displays weaknesses in all judgments: one important blind spot is the failure to include the child's views in the decision-making process. The development in terms of delivering rational, well-reasoned and thorough judgments is nonetheless positive. Furthermore, the Supreme Court's recognition and protection of the child's de facto family situation correspond to observed developments in the European Court of Human Rights as well as in national state policy on adoption.
\end{abstract}

\section{Keywords}

adoption - Supreme Court - legitimacy - best interest - justifications - rational decisions - deliberative democracy - discretion 
Sitting at the apex of the Norwegian judicial system, the Supreme Court has the power to govern citizens in its jurisdiction through its authority, and the responsibility to justify certain orders or actions. In this case, the court must justify the decision on whether a child should be adopted by his or her foster parents against the will of the biological parents. Under the separation of powers, the Supreme Court is assigned to be the guardian of the constitution. Its task in deciding on adoption from care is that of, on the one hand, controlling the actions of the public administration and, on the other, to interpret democratically constituted law and policy and authorise the exercise of political power (Eriksen and Weigård, 1999). The practices of the Supreme Court are precedential (Bårdsen, 2016), and the Court's judgments have not only a considerable impact on the practices of the lower courts and for actors making decisions on child welfare matters but also the power to influence policymaking outcomes and to create law (Hirschl, 20o9; Magnussen, 2006, Schei, 2015). This article studies the Norwegian Supreme Court's decisions concerning the best interest of a child in four judgments on adoption from care. ${ }^{1}$ In Norway, children have a constitutional right to have their best interests considered in matters that concern them (Sandberg, 2019), yet the principle is notoriously ambiguous and indeterminate (Mnookin and Szwed, 1983; Elster, 1989; Kohm, 2008). To determine what is in the best interest of the child, Norwegian decision makers are provided with extensive discretion (Skivenes and Sørsdal, 2018) and are required to make normative choices concerning what is a good life and to balance different citizens individual rights and interests. Such circumstances leave these decisions open to questions about their legitimacy. Accordingly, we require in-depth and substantive knowledge about the decisions made while being required to acknowledge that the nature of best interest decisions warrants their subjection to democratic control. Researchers of the Supreme Court's decision-making concerning adoption judgments have identified shortcomings or deficits in the Court's reasoning, including its failure to take a child-centric approach (Sandberg, 2016), ambivalence (Helland and Skivenes, 2019), and not meeting the standards of rational decision-making (Skivenes, 2010). In other areas of child and family law, the Court has been criticised for its overly judicial understanding and application of the 'best interest principle' (Jerkø, 2018), its flawed legal approach concerning the need to establish formal contact (Riiber and Syse,

1 Rt. 2015 S. 110 ; Rt. 2015 S. 11O7; HR-2018-1720-A; HR-2019-1272-A. 
2018), and its failure properly to acknowledge the child's right to be heard (Haugli, 2020).

The objective of this study is twofold. The first aim is to assess the legitimacy of the decisions from a deliberative perspective on decision-making: Are the best interests decisions rational? The second is to map and analyse the justifications applied in the practical argumentation concerning the child's best interests: how does the court justify its decisions?

In the tradition of deliberative democracy, I consider the Supreme Court's capacity to produce justified and rational decisions through deliberative decision-making procedures to be vital for meeting its responsibilities as the guardian of the constitution. Inherent in the deliberative model is the idea of the "force of the better argument' (Habermas, 1975: 108), meaning that decisions should be supported by good arguments - wherein "good" is premised by the arguments' foundation in a mutual discussion where all involved have an equal and unhindered voice. The argumentation of the Court thus depends on the quality of the procedures in the justification process, and it is considered rational if it occurs through rational discourse guaranteed by certain requirements and standards (Alexy, 1989; Habermas, 1996). I return to this matter in Section 4. Positioned within a Habermasian research programme, I build on a discourse theoretical approach from Skivenes (2010), who developed a vigorous analytical framework critically to analyse the rationality of the Supreme Court's best interests decisions. I advance this framework by including a critical analysis of the court's justifications of its judgments and, thereby, add both to the theoretical framework and to the empirical knowledge of the Supreme Court's decision-making. It should be clarified that this is not a legal analysis, but one premised on social science methods and epistemology.

The following section presents the background and purpose of the study, followed by an outline of the main features and requirements for adoption decision-making in Norway in Section 3. Next, the theoretical and conceptual basis for the analysis of court judgments is provided in Section 4, followed by a methodological outline and limitations presented in Section 5 . In Section 6, the findings are presented and the arguments evaluated, and in Section 7 , the discussion is presented. Finally, some concluding remarks are made in Section 8.

\section{$2 \quad$ Background}

Adoption from care is uncommon in the Norwegian child welfare system, and less than one per cent of children placed in foster care are adopted each year 
(Helland and Skivenes, 2019). ${ }^{2}$ While neither the recent policy development for encouraging adoption (Tefre, 2020) nor the legal conditions for adoption set a particularly high threshold for consenting to the adoption, case law does. The European Court of Human Rights (ECtHR) requires a decision on adoption to be based on, 'an overriding requirement pertaining to the child's best interests' (Appl. no. 17383/9o, para. 78). In Norwegian case law, 'particularly weighty reasons for adoption' is found to suggest the same norm (Sandberg, 2020). Furthermore, Article 8 of the European Convention of Human Rights (ECHR) requires that in instances where the interests of a child and his or her parents' conflict, a fair balance (Council of Europe, 1950) should be struck between these interests, although those of the child may override those of the parents. ${ }^{3}$ Between 2015 and 2019, 13 cases concerning adoptions without parental consent were communicated to Norway by the ECtHR. Of these 13, only one had been tried by the Supreme Court. In September 2019, the ECtHR Grand Chamber ruled that the Norwegian state had violated Article 8 of the ECHR on the right to respect for private and family life when consenting to the adoption of a young boy without the biological mother's consent (Strand Lobben and Others v. Norway [GC] 2019).

Since the implementation of the Norwegian Child Welfare Act (CWA) in 1993, the Supreme Court has delivered judgment in no more than seven cases on adoption from care. The four most recent judgments are analysed in this paper, which were all delivered within the short period from 2015 to 2019, when the Norwegian state was subject to comprehensive international legal scrutiny. Skivenes (2010), who studied the three Supreme Court judgments ${ }^{4}$ preceding the four analysed in this study, concluded that the first two decisions (1997 and 2001) were not made according to rational standards, whereas the latest decision (2007) was. The objections were aimed particularly at the court's lack of child-centric reasoning, which was interpreted as conflicting with current policy.

\section{Adoptions in Norway: Features and Requirements for} Decision-making

In the context of child welfare decision-making, interventions are guided by the principle of the least intrusive form of intervention, the biological principle and the best interests principle (Lindbo, 2011). These entail that while the

\footnotetext{
2 In Norway, adoption and long-term foster care are the only permanent options for children who cannot return to their birth parents.

3 For example, Strand Lobben and Others v. Norway [GC] 2019, para. 206, see Sørensen (2020).

4 Rt-1997-534; Rt-2001-14; Rt-2007-561.
} 
best interest of the child should be decisive in the decision whether to permit adoption, the court should seek to limit intrusion into the family and facilitate continued contact between children and their parents. Adoption from care without parental consent is possible through the CWA (1992) section 4-2O Deprival of parental responsibility - Adoption, which consists of four cumulative conditions, as follows: (a) The biological parents are permanently unable to provide proper care, or the child has become so attached to his/her new environment that removal will lead to serious problems; (b) Adoption is in the child's best interest; (c) The adoption applicants are the child's foster parents, and they have proven fit to care for the child; (d) The conditions of the Adoption Act are satisfied. If a child is under public care by an official care order, the local child welfare authorities can initiate an adoption and bring it to the court-like decision-making body the County Social Welfare Board (the board), which holds the authority to decide on compulsory measures. A decision from the board can be brought before the ordinary court system (see Table 1), with the Supreme Court as the highest appeal court.

\subsection{The Discretion of the Supreme Court and the Best Interests Principle}

The Norwegian Supreme Court is a court of general jurisdiction and is usually presided over by 5 out of 20 judges (Grendstad, Shaffer and Waltenburg, 2010). The deliberations are highly proceduralised and take the form of 'formalised discussions', where all five judges are allocated time to present their views (Grendstad et al., 2019). The final decision allows for dissenting opinions, and the judges may change their opinion during the deliberations. Opinion writing is a shared responsibility, and decision drafts are circulated among the judges on the panel before the decision is presented and discussed at a minimum of two conferences following the oral hearing. For the court to admit a case, questions must be raised of a principled character beyond the concrete circumstances of the case or for other reasons which are of particular importance to hear. ${ }^{5}$ In other words, Supreme Court cases are extraordinary and require deliberation by highly trained decision makers.

Judicial decisions are based on two sources: rule and discretion (Dworkin, 1963). If the court has the discretion to interpret what is in the best interest of a child - the rule - the basic democratic ideal that those subjected to norms

5 The Supreme Court is to review, under section 36-5 subsection 3 of the Dispute Act (Act relating to mediation and procedure in civil disputes (2005)), all aspects of the case, and the review must be based on the situation at the time of the judgment. In cases such as this, the court does not hear witnesses directly in the court, but through written statements or depositions. Court-appointed experts may be examined directly before the court. 
must be able to be the author of these norms (Forst, 2016) and the principle of popular sovereignty, which entails that legitimate state power should emanate from the people (Locke, [1698] 1988), are challenged. Discretion further challenges the fundamental democratic principles of predictability that equal cases are treated equally and different cases treated differently. The most commonly contested condition for adoption to be approved in Norway is the best interests of the child (Helland and Skivenes, 2019). Article 3 of the United Nations Convention on the Rights of the Child (CRC) (1989) states that, 'the best interests of the child shall be a primary consideration' in all decisions that concern children. This principle is strongly anchored in Norwegian law, where the CRC applies as statutory law ranked above ordinary legislation after its incorporation into the Norwegian Human Rights Act in 2003 (Sandberg, 2019). In 2014, the best interests principle was enacted in the Norwegian Constitution in Grunnloven ([1814] 2014) (Article 104(2)). Section 4-1 of the CWA requires the best interests of the child to be the guiding consideration in implementing measures and emphasises the importance of providing the child with continuity (permanence) as well as stable and good adult contact (Skivenes and Sørsdal, 2018). In addition, the CWA requires the child's participation to have a decisive position in best interest consideration (Skivenes and Sørsdal, 2018), and through Article 104(1) of the Constitution and CRC Article 12, children have the right to be heard in cases that concern them (Sandberg, 2019). Relating to adoption, in particular, General Comment No. 14 (Committee of the Rights of the Child, 2013) concerning the best interests principle states:

In respect of adoption (art. 21), the right of best interests is further strengthened; it is not simply to be 'a primary consideration' but 'the paramount consideration'. Indeed, the best interests of the child are to be the determining factor when taking a decision on adoption, but also on other issues.

The best interests of the child is also a condition under the Norwegian Adoption Act (2017) and a specific condition under section 4-20 and can be characterised as a rule in cases on adoption (Bendiksen, 2008). In summary, best interests assessments are fundamental to decisions on adoption, but the legal interpretation of the best interests principle is largely founded on vague rules, ${ }^{6}$ and there is an indeterminacy associated with a best interests evaluation, provided primarily that any universal or unitary form of measure to such a standard is difficult, if not impossible, to agree upon. Thus, committing to reasoning based

6 See discussion on vague rules in hard cases in Dworkin (1963). 
on a best interests claim must include either implicit or explicit deliberations of a value-based and normative character. In the tradition of argumentation theory, such factual and normative conflicts should be addressed through rational discourse (Skivenes, 2010), and one approach to securing rational best interests decisions is to ensure that they are reached through a reasoned deliberative process (Archard and Skivenes, 2010).

To analyse the judgments, this article builds on Skivenes's (2010) approach to study the rationality of decisions in the legal context. Skivenes's model builds on theories of argumentation from the tradition of Alexy (1989) and Habermas (1996) and is based on an evaluation of whether the court's validation of claims meets the discourse ethical standards, adheres to the rules of rational argumentation, and follows the rules for deliberative processes. The understanding of rationality in this context derives from the theory of practical discourse and communicative action, where the idea is that the aim of everyday discourses is that of reaching a common understanding through the exchange of reasons for or against a given claim or assumption. This exchange relates to law through which Habermas (1990, 1996) defines a complementary relationship between rationality in legal discourse and that in everyday discourse, where legal procedures are considered to promote rationality in discourses on moral issues.

To assess how the court resolves a conflict, I distinguish between claims that adhere to pragmatic, ethical or moral discourses (see Feteris, 2017; Habermas, 1996; Skivenes, 2010; Eriksen and Weigård, 1999; Huttunen and Heikkinen, 1998) and link them to their respective standards for evaluation.

Pragmatic discourses concern selecting the option that is more feasible or efficient to reach a given goal and should be substantiated by reference to established and scientific methods and/or empirical observations. Claims within this discourse are oriented towards empirical facts regarding a situation, for example, professional knowledge and evidence, in the context of establishing the most appropriate means to achieve a goal. The standard of evaluation is whether statements are true, documented, reliable and realistic.

Ethical discourses concern which values are worthy of united effort and what a good life is. Claims in this discourse concern the values and interests to pursue, for example, in relation to what constitutes a good childhood. The standard of evaluation is hermeneutical interpretation related to the cultural and social norms and practices in the context of the given community. 
Moral discourses concern claims about moral rightness and argumentation is oriented towards universalisation. Claims in this discourse are concerned with respecting normative rights and conceptualisations of what parties are owed in terms of justice and fairness: what is an outcome that can be considered right and fair for everyone? To be perceived as rational, the final outcome must be generalisable in a decontextualised form in such a way that all parties concerned can accept it as their own. ${ }^{7}$

Following the theory of deliberation, decision-making should be a deliberative process with the premise that it 'rests on good information regarding the contents of the case and the parties' situations, that possible choices of action and their consequences must be explored, and that possible results should be ranked in relation to overall goals' (Skivenes, 2010: 341-342). In addition, the basic rules for process state that all persons can participate, that they can propose any assertion that they wish, that they believe in their assertions, and that they aim to be consistent in their use of words and concepts (Skivenes, 2010; Eriksen and Weigård, 1999).

The presuppositions of rational argumentation can be divided into three levels: the logical level of products, the dialectical level of procedures, and the rhetorical level of processes (Feteris, 2017). At the two first levels, the evaluation is based on the demands that speakers should not contradict themselves, and their arguments should be consistent and logical, their statements must be generalisable, and they should avoid ambiguity. Furthermore, they should be sincere in their assertions and provide reasons for disputing a proposition or norm not under discussion. The third level sets the criteria for our "rules for rationality" and stipulates that all statements (arguments) must be reasoned if a statement is countered or questioned, unless there are reasons not to do so (then such reasons shall be given). Moreover, all persons can participate in the discourse, freely proposing and problematising any assertion they wish to while not being hindered from exercising any of the former actions. In addition, the rational rules for the allocation of the burden of proof state that the principle of universalisability requires justification of all suggestions for treating one person differently from another, and only assertions that are challenged should be justified. Irrelevant utterances and statements should be avoided or at least justified. In principle, decisions that emerge through genuine deliberative processes should be acceptable to all by the standard that the parties cannot reasonably reject them. This further necessitates that we ask whether relevant interests and considerations relevant to the field are

7 For a presentation of the principle of universalisation $(\mathrm{U})$ as a rule of argumentation, see Habermas (1990). 
included in the deliberation. Based on this conceptual corpus, the analysis of the written judgments aims to:

Evaluate the quality and rationality of the court's argumentation by the standards that:

- the argumentation is logical, relevant, coherent, sincere and unambiguous

- the argumentation is supported by reasons

- the parties are freely included and heard

- claims meet the standards of evaluation and can withstand critical scrutiny.

Expose caveats and weakness in the court's argumentation and deliberation process:

- missing arguments are identified

- the arguments are justified

- the arguments are weighed and balanced against each other.

For a multifaceted approach to the evaluation of legitimacy, I also analyse the court's practice of justification in relation to a broader set of thematic discussions to call attention to value presuppositions, logics and normative structures inherent in the decision-making. In summary, the theoretical framework serves three complementary purposes in our quest to analyse the legitimacy of the decisions. First, it concerns the rational resolution of conflicts about facts and values. Second, it suggests how the decision-making process can be conceived as democratic. Third, it indicates how implementing the law through discretionary decision-making practices takes the form of justifications of dominant perspectives and ideas (Sinclair, 2005). In the analysis, I draw some general lines of argument from the cases and present only the most pressing caveats and interesting findings from the viewpoint of legitimacy. Finally, it is important to point out that even if we conclude that a decision is rational and legitimate, this does not imply that it is necessarily the correct one, as even rational consensuses are fallible and can be provisional (Eriksen and Weigård, 1999). Moreover, in real-world practical discourses, the expectation is that the criteria can only be fulfilled to a certain degree.

5

\section{Methods}

The empirical data consist of four written full-length Supreme Court judgments on adoption from care under section 4-20 of the cws. Two of these were decided in 2015 (hereinafter referred to as $2015 \mathrm{a}$ and $2015 \mathrm{~b}$ ), one in 2018, and one in 2019. These four are all the judgments made from 2015 to 2019. As 
the three preceding judgments from 1997, 2001 and 2007 were studied using a similar methodological and theoretical approach by Skivenes in 2010, these are excluded from the analysis. The judgments are publicly available; they were retrieved from the Lovdata.no (PRO) national database. The documents follow a structure where the reasoning of the decision makers is presented in the last section of the judgment, proceeding from a presentation of the facts, a summary of previous decisions in the lower courts (including the board), and the parties' arguments and claims. Within the court's reasoning, only the best interests assessment is subject to analysis. The documents vary in length from 8 to 14 pages, where the court's reasoning constitutes between 4 and 9 pages, respectively.

\subsection{Qualitative Text Analysis}

The study is based on a qualitative analysis of the judgments, using an approach inspired by thematic and classical legal argumentation analysis (Coffey and Atkinson, 2006; Feteris, 2017). The coding of the arguments was conducted as a back-and-forth process, whereby individual arguments and their reasoning were identified and simultaneously defined as related to clusters of arguments, which will be referred to as "justificatory themes". In the process of developing the categories for the justificatory themes, I used a coding schema that emerged mainly through an inductive approach to the data, although both the schema and the coding were formed by research and previous knowledge. After the first step of categorisation, the arguments were defined by discourse and dissected to identify the reasoning behind them. The systematised data were then analysed and evaluated according to the standards delineated in Section 3 .

Depending on the context in which it appears, where the weight of reasoning is placed, and the general construction of the argument, elements or claims that are considered to be arguments in one case are not necessarily given the same status in another. While recognising that such an approach could entail that aspects of interest from a legal point of view will not be discussed, arguments of a legal or procedural nature will not be pursued in the presentations or discussions, and I will not pursue any inquiry into the court's interpretation of national and international law and jurisprudence.

\subsection{The Cases - A Brief Overview of the Basic Characteristics}

Even though the question of reunification is addressed in 2015a, the best interests of the child is essentially the disputed theme of the decisions in all four decisions. As reunification is not considered to be a feasible option: the decision concerns the choice between continued foster care and adoption. None 
TABLE 1 Key features of judicial proceedings in the four decision-making instances: Result of the decision, dissenting opinions and year of decision.

\begin{tabular}{|c|c|c|c|c|c|}
\hline & Instance* & The Board & DC & CA & SC \\
\hline \multirow[t]{3}{*}{$2015^{a}$} & Result & Adoption & Adoption & No adoption & Adoption \\
\hline & Dissent & No & No & No & No \\
\hline & Year & 2012 & 2013 & 2014 & 2015 \\
\hline \multirow[t]{3}{*}{$2015^{b}$} & Result & No adoption & Adoption & No adoption & No adoption \\
\hline & Dissent & No & No & Yes: $2-3$ & No \\
\hline & Year & 2013 & 2014 & 2015 & 2015 \\
\hline \multirow[t]{3}{*}{2018} & Result & Adoption & No adoption & Adoption & Adoption \\
\hline & Dissent & No & Yes: $2-1$ & Yes: 4-1 & No \\
\hline & Year & 2016 & 2016 & 2017 & 2018 \\
\hline \multirow[t]{3}{*}{2019} & Result & Adoption & Adoption & Adoption & Adoption \\
\hline & Dissent & Yes: $2-1$ & No & Yes: $3^{-2}$ & No \\
\hline & Year & 2017 & 2018 & 2019 & 2019 \\
\hline
\end{tabular}

* THE BOARD = THE COUNTY SOCIAL WELFARE BOARD, DC = THE DISTRICT COURT, CA $=$ THE COURT OF APPEAL, SC = THE SUPREME COURT.

of the judgments had dissenting opinions, and in three out of four cases, the Supreme Court ruled in favour of adoption (see Table 1). In 2015b, the father acts as the sole party to the case in the Supreme Court as the child's mother passed away in 2014. The children were aged six and a half $(2015 \mathrm{a}, 2015 \mathrm{~b}$, and 2019) and five (2018) years at the time of the Supreme Court decision. They had been in out-of-home care since they were two and a half months old (2015a), eighteen months old (2015b), newborn (2018), and nine months old (2019). The reason for removal in all cases was neglect, and the child in the 2019 case was also exposed to abuse.

\subsection{Limitations}

The analysis is based solely on written material, which entails some limitations. First, the judgments are authored in retrospect and for a particular purpose - to validate the legality of the decision (Eckhoff and Helgesen, 1997). Second, the documents do not necessarily include all information that would be considered essential or interesting from a research point of view, and one must be aware that judicial decisions do not provide a complete picture of the individual case (Magnussen, 2006). Nonetheless, the Court is legally obligated to justify its decisions (the Dispute Act, section 9-6), and the arguments will reflect the reasoning that the Court defines as the official argument, which will prevail for later decisions and judgments in the area (Magnussen, 2006). 
Overall, 15 different arguments are included in the decisions (see Table 2). The arguments are linked to four overreaching justificatory themes: the right to a "new" family or, in other words, for the child to remain in the foster family, the right to biological family life, the child's autonomy and development, and time. Pragmatic arguments appear most frequently, and if ethical values are considered, they usually coincide with pragmatic concerns, within predominantly pragmatic discourses. Moral discourses, with one exception, are absent. The number of arguments included in the courts' decisions increases consecutively with time: the $2015 \mathrm{a}$ and $2015 \mathrm{~b}$ judgments included 6, 2018 included 10 , and the 2019 judgment included 12 arguments. Five arguments were reiterated in similar form in all four judgments: the child's strong attachment to the foster family, the general knowledge that adoption provides better prospects in life than remaining a foster child, the weak or absent de facto relations with the biological parent(s), the child's vulnerability, and the risk of future conflict. Below, I present the 15 arguments and evaluate their quality in terms of rationality, structured by the four thematic dimensions.

\subsection{The Right to a "New" Family}

On the theme of the right to a "new" family, discussions revolve around the situation in the foster home and of the family in the abstract or non-biological sense. Six arguments were identified as pertaining to such discussions. The pragmatic arguments concerned the attachment between the child and the foster parents and the de facto situation of the child. Two arguments, the general knowledge that adopted children are generally better off in the end than their peers that remain fostered and that adoption will provide stability and a home for life, adhere to pragmatic and ethical discourses. The latter is often seen as a condition for the former, and the arguments are highly interrelated. Another two arguments include claims of an ethical nature, that of normalisation and stabilisation of the child's everyday situation and that of equality.

\subsubsection{Argument 1. Strong Attachment to Foster Family}

In $2015 \mathrm{a}$, convincing references to the facts of the situation, general knowledge, and expert statements are advanced, and the argument is considered to be reasonably justified. The same elements are present in $2015 \mathrm{~b}$, but there is less reasoning, and the descriptions of the current situation could be embellished further. In the 2018 judgment, the argument is also somewhat briefly but adequately - reasoned: 


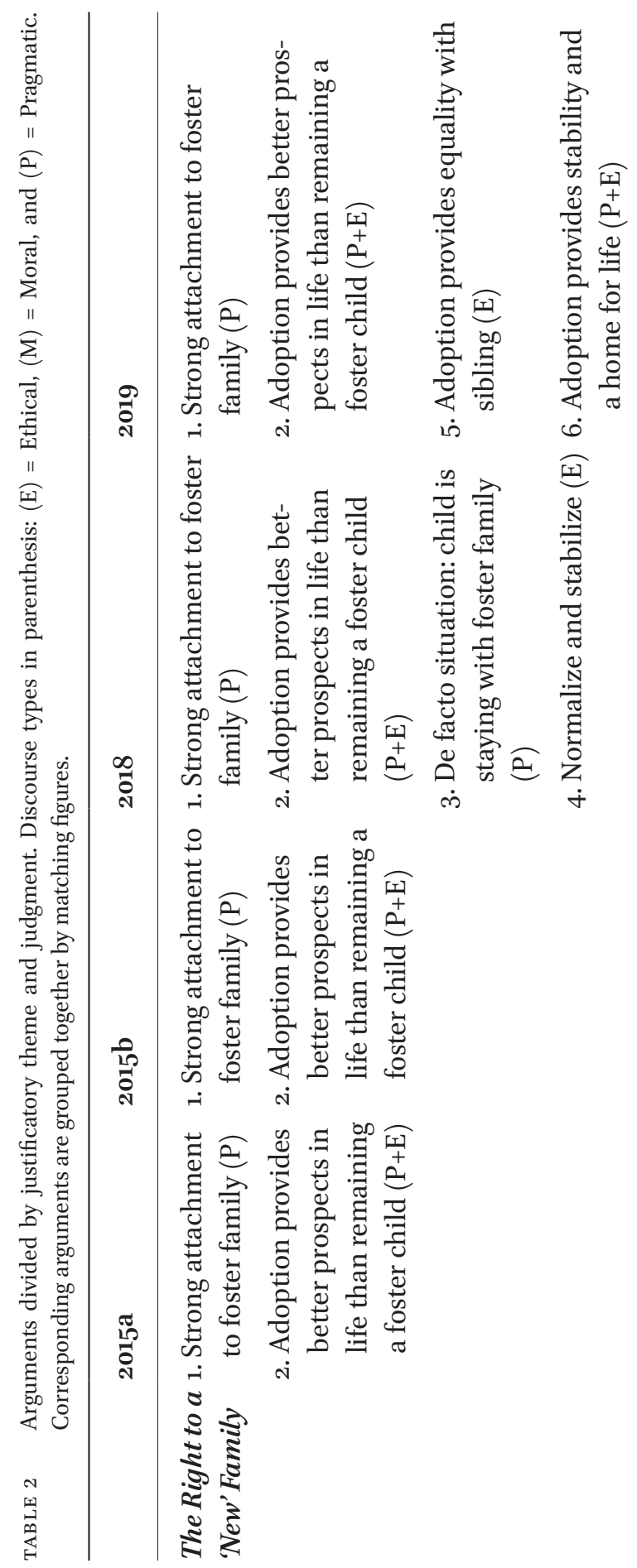




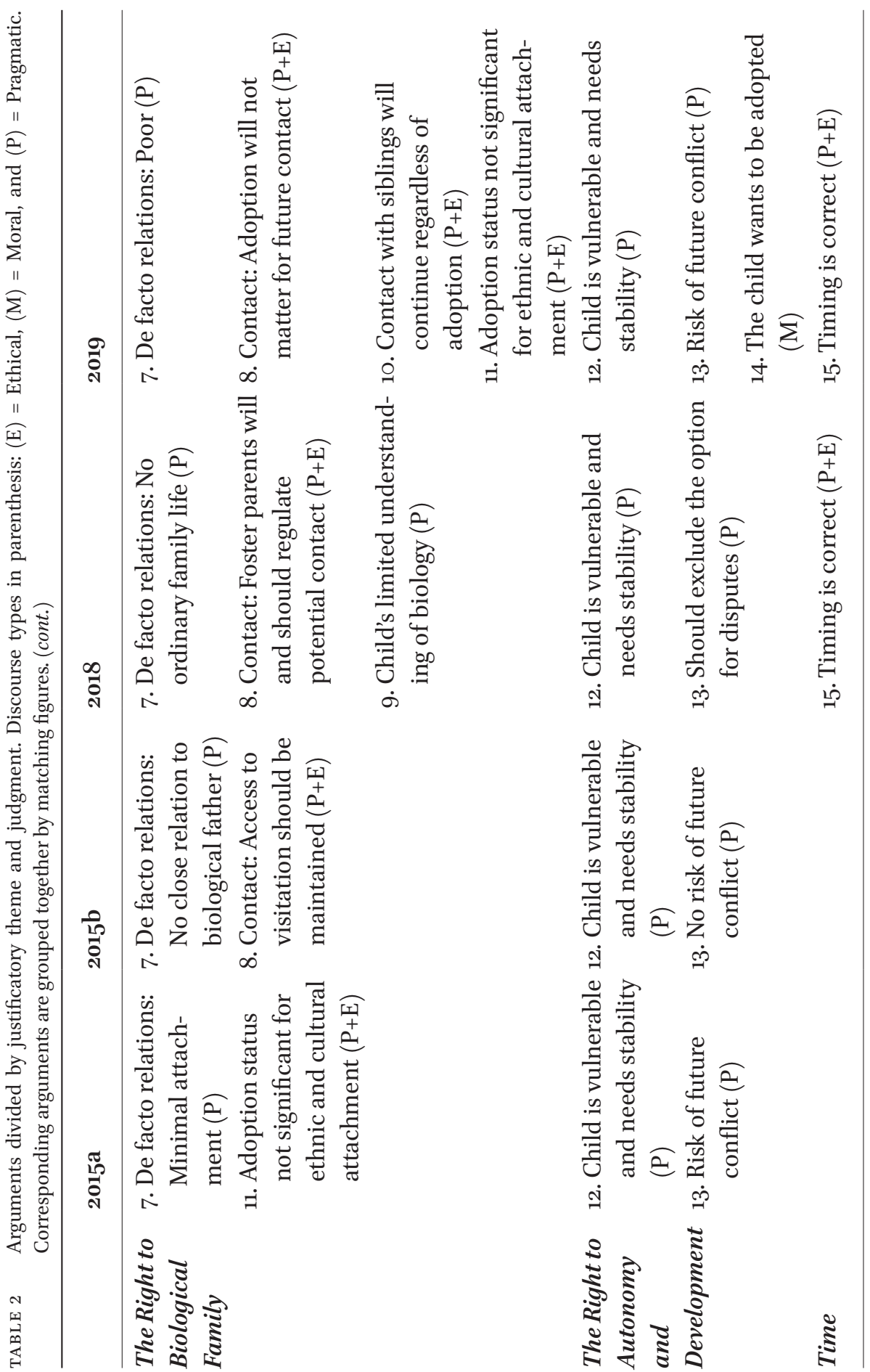


The expert has emphasised that [the child] ${ }^{8}$ has a full and exclusive sense of belonging to the foster home. I assume that all arrangements are made for [the child] to have the best possible development in the foster home.

HR 2018-1720-A, PARA. 78

In the 2019 judgment, the argument includes descriptions of the previous and current situations, with expert and witness statements, and it is justified in a thorough and reasonable manner. In relation to 2015a and 2019, it should be mentioned that the child's siblings in the foster home, and the extended family in the former case, are included in the reasoning of his attachment. While it is not known whether there were any siblings in the foster home in the 2018 case, we know that the girl in $2015 \mathrm{~b}$ had a foster brother ${ }^{9}$ whose relationship with the girl is not included in the court's reasoning. The child's attachment to his foster family was given considerable weight in 2015a, while no specific weight was given to this argument in the other three cases.

6.1.2 Argument 2. Adoption provides Better Prospects in Life than remaining a Foster Child

A caveat of this argument in 2015a, 2015b, and 2019 is that the general knowledge claim is not substantiated with references to the factors that make adoption a better option for the child, although an official report is cited in 2015a, and in 2019, the argument is supported in part by an expert's statement on the matter. Furthermore, discussion on issues including relevant ethical values is limited. The argument is thus considered to be partly reasoned for 2015a, $2015 \mathrm{~b}$, and 2019, yet stronger in the first and third of these cases as the reasoning is more inclusive. In the 2018 judgment, the claim is substantiated with references to a review of the current research undertaken by the appointed expert, whose statement is also cited:

Children in long-term foster care that are adopted, undergo better psychosocial development than children in a similar situation who are not adopted. It is the durability of the child's sense of belonging that seems to be essential.

HR 2018-1720-A, PARA. 64

Based on this and the brief discussion that followed on the value of a safer and more predictable upbringing in relation to the two options of foster care or adoption, the argument is considered to be justified.

8 Text provided in brackets has been added by the author for clarification.

9 Known from the judgment from the Norwegian Court of Appeal (LE-2014-148984). 
6.1 .3

Argument 3. The De Facto Situation: Child is Staying with Foster

Family

The argument is supported by reference to the fact that reunification is not a realistic option, which the biological parents, while not agreeing to adoption, have also accepted. As the justification criterion for pragmatic claims is that of truth and realism, the situation that the child's de facto family life is with the foster home is agreed by the parties, and the argument is considered reasonably justified. The biological mother expressed the following view to the appointed expert before the Supreme Court:

I have accepted that I will never have the chance to bring him home, that he stays where he is, but without being adopted. After all, he has been there since he was one ...

HR 2018-1720--.A, PARA. 67

\subsubsection{Argument 4. Normalise and Stabilise}

The argument is considered justified, and the claim is that adoption will normalise the child's exceptional situation of being in foster care, with its practical and emotional implications for a child's everyday life. The expert declares:

By consenting to the foster parents adopting [the child], society may provide him with this protection [from change and insecurity] through the Supreme Court's judgment.

HR 2018-1720-A, PARA. 80

While the court justifies the argument reasonably based on ethical considerations concerning stabilisation and normalisation of the child's situation, it qualifies the child's need for a stable life situation by referring to the experts' statements about its importance, reframing the ethical considerations to be subjected to truth validation based on expert knowledge.

\subsubsection{Argument 5. Adoption Provides Equality with Siblings}

The argument is that the child should gain equal status and the same name as his adopted sister, labelled his "social sister", as this is considered important to him. With hermeneutical interpretation related to contextual cultural and social norms and practices as the standard of evaluation, the court justifies the argument reasonably based on ethical considerations of why equality matters. As for argument 4, the court qualifies their ethical claim by referring to expert statements. 
6.1.6 Argument 6. Adoption Provides Stability and a Home for Life This is a well-reasoned argument about the stability and belonging that adoption would provide. The claim is backed by expert knowledge, alternative outcomes are explored, descriptions of the situation are given, and value-based reflections on the matter are provided in the Court:

[The child] is in a good and stable situation in a well-functioning foster family that wants to adopt him, and adoption will provide stability and tranquillity to this situation and give him inner peace. In contrast to a foster care arrangement that generally only last until the child turns 18 , an adoption lasts for life.

HR-2019-1266-A, PARA. $101^{10}$

\subsection{The Right to Biological Family}

Five arguments were found to adhere to an overarching discussion on the right to biological family life. Three claims adhere to both pragmatic and ethical discourses, and two concern pragmatic arguments. The arguments relating to the child's poor relations and weak attachment to his or her biological origin are juxtaposed with corresponding claims relating to the relations and strong attachment to the foster family and current environment in all decisions, although less so in the 2019 decision. The first of these two arguments receives less attention in terms of the reasoning provided, and one possible explanation for this is that the court views the second argument as explanatory of the first.

\subsubsection{Argument 7. De Facto Relations: None or Weak}

In the two 2015 judgments, the consideration of relationships between the children and their biological parents is given little explicit attention. Nonetheless, in 2015a, the argument is considered adequately reasoned, as there are references to empirical facts, such as the child's early placement in out-of-home care and expert evidence, while this cannot be said about the 2015 b case. Rather, it revolves around the contact itself and its established and predicted implications. Seen in the context of the overall judgment, one would expect this matter to be the target of particular scrutiny in $2015 \mathrm{~b}$ as contact and biological ties (as legal bonds) are the decisive factor in the decision. This is not the case, and the only reasoning around the issue is the following:

10 All citations from the 2019 judgment are translated by the author, as no translation is provided through Lovdata.no. 
She has lived in the foster home for four years, and has no longer a close relationship with her father.

RT. 2015 S. 1107 , PARA. 48

In 2018, the absence of actual family life and previous and current social bonds is highlighted. The argument is based on the fact that the child was placed in the foster home at birth and had no contact with the biological parents since. In the 2019 judgment, the argument is given considerable weight, and the court emphasises that the limited time he had spent in the care of his biological parents, rather than having contributed to a safe and good relationship with them, had been detrimental to him owing to the neglect he experienced. In both the 2018 and 2019 cases, the arguments are reasonably justified.

\subsubsection{Argument 8. Contact}

The argument is thoroughly reasoned with expert evidence and descriptions of the actual situation in the $2015 \mathrm{~b}$ decision. As for the ethical concerns inherent in the argument, the argument is weakly justified, as the benefits of contact from the perspective of the child are not adequately considered. The reasoning is strongly focused on the father's character and abilities, applied by the court as a measure of credibility of future co-operation. Although one would necessarily agree that it is a good thing for a father to have good qualities and to care about his daughter, the court foregoes a discussion on the child's needs and her personal reflections. Furthermore, the statement supporting the argument that the child does not lose out from postponing the decision lacks the necessary resonance:

Out of concern for the child's secure and stable base at the foster home, I find - like the majority of the court of appeal - that the child does not have much to lose from a postponement of the adoption issue until her needs and relationship with her biological father have been further clarified.

RT.2015: 1107, PARA. 56

These unresolved needs are not identified, and it is unclear what matters and needs require further clarification. Moreover, reflections relating to the value of childhood as a temporary state would be expected, as there is no timeline given for re-establishment of contact. The argument contradicts previously endorsed arguments concerning children's development, and there is ambiguity and duality in the reasoning regarding the foster parents' positive outlook of future contact between the child and her father that the court foregoes to 
address. In the 2018 judgment, the argument is based on a claim that the parents should regulate contact. The argument is given weight and is reasoned with reference to expert statements that the foster parents are receptive to contact - with the rebuttal that this does not provide any legal rights to contact for either the child or the parent - and the presumed implication of heightened tranquillity and safety in the placement. The justifications for the argument are thorough and inclusive, and they include reasoning on the value of contact. In the 2019 judgment, the claim is that adoption will not matter for the extent of contact the child will have with his biological parents. The reasons refer to the previous unsuccessful attempts to sustain contact, mentioning that the child does not have contact with his parents as the case stands and that his foster parents do not exclude future contact if the child expresses such a wish. This appears only partially reasoned, because it does not address why contact is considered to pose a potential hazard for the child. Moreover, the possible implications for the child's life of not having contact with his parents could have been more explicitly elaborated.

\subsubsection{Argument 9. Child's Limited Understanding of Biology}

The argument concerns the child's understanding of biology, and the court questions whether the boy, owing to his developmental disabilities, will ever be able to understand what it means to have a "biological" family. It refers to the appointed expert's statement on the matter:

Today, [the child] is in any case not able to see that he has other parents than his foster parents. Due to his particular vulnerability and need of safety, it would, in the expert's opinion, be detrimental to him if the biological parents were to introduce themselves as "mother" and "father", and a trial arrangement with contact visits 'would be like experimenting with the boy's mental health'.

HR 2018-1720-A, PARA. 86

The argument is given weight by the court, which assesses whether the statements are considered true, documented and realistic. Given the standard of evaluation for claims of empirical facts, the argument is considered reasonably justified.

Argument 10. Contact with Siblings will Continue Regardless of Adoption

The argument is that the boy will continue the contact he has already established with his two biological siblings, who have also been placed in foster care, 
even if he is adopted. The situation is explained, and the court assesses the probability of breakdown in contact and of the possible damage to the siblings' relationships if one were adopted. They do this by reference to expert statements and current arrangements for maintaining contact:

[The child] and his two biological sisters live in three different foster homes near each other. The eldest sister's foster father is the brother of [the child's] foster mother. The siblings attend different schools, but meet, among other, on a monthly sibling meeting and stay in contact also in other ways. The foster mother states that it will not matter to the sibling contact if [the child] is adopted.

HR-2019-1266-A, PARA.91

The argument is considered reasonably justified, although with the caveat that a fourth sibling is not a part of the discussion by virtue of not having met the boy. Similar arguments relating to biological siblings are not present in the other three judgments, although all the children have one or several (half-) siblings. ${ }^{11}$

\subsubsection{Argument 11. Adoption Status is not Significant for Ethnic and Cultural Attachment}

In the 2019 judgment, the court concludes that the boy's attachment to the culture of his origins is nonetheless enduring with the break from his parents and that consenting to an adoption is not considered to be of any particular relevance for the boy's cultural connection:

The expert has pointed out that [the child] lives his everyday life in a Norwegian environment and will necessarily obtain a Norwegian identity. Eritrean culture may interest him as he grows older, and he may miss this connection. However, this applies regardless of whether he is a foster child or an adoptive child.

HR-2019-1266-A, PARA. 94

Emphasis is put on the foster parents' efforts to maintain bonds with his culture, and his contact with his sister is also considered positive. I find this to be thorough and reasonably justified on this point. Yet, the lack of attention to possible issues that may arise from the child's status as a member of an

11 Known from the judgment in the District Court (твомS-2012-126359) in 2015a and the judgment by the Court of Appeal (LE-2014-148984) in 2015b. 
ethnic minority, in his adoptive family and in the community, is an apparent weakness in terms of the ethical concerns related to such a claim, particularly as the child himself appears to be aware of his ethnicity. With reference to a statement from the expert who had talked to the boy, one of his wishes was reported as follows:

'[The child] is 6 years old and mature enough to understand the external consequences of adoption. He wants to have the same status as [sister] who is the adoptive daughter in the family and who also has a dark complexion....

HR-2019-1266-A, PARA. 87

In 2015a, the boy's biological mother is of another ethnic background from his foster parents, so contact is considered particularly relevant in terms of maintaining biological bonds. The judges argue that these bonds are safeguarded through the post-adoption contact visits that they trust will function as intended. A weakness is that no reasons are provided for why and how this contact would benefit the child in terms of his biological and ethnic background, or why the allocated degree of contact is considered appropriate for the intended purpose. The argument is considered to be only partly justified considering the lack of support for the claims.

\subsection{The Right to Autonomy and Development}

Three arguments belonged to this category, and two themes are apparent in all judgments: the child's vulnerability and the risk of future conflict. Both were pragmatically founded and highly interrelated, where the child's vulnerability is highly indicative of the perceived risk. The third argument is moral, relating to the child's opinion, and it is the only argument of its kind.

\subsubsection{Argument 12. The Child is Vulnerable and Needs Stability}

The argument is given considerable weight in 2015a and is reasonably justified by referring to the consistency of previous evaluations of the child's special needs. There are extensive references to empirical facts, expert evidence, reports and statements from the school and the Educational-Psychological Service, as this excerpt illustrates:

The Educational-Psychological Service has, in their assessment, pointed out 'the need for stability, predictability and security in that he knows who will be taking care of him and who he should go to'. A statement 
from his teacher of [date] states that he has settled down at school, but that he has trouble concentrating and has very little self-confidence

HR-2019-1266-A, PARA. 87

References to empirical facts and expert evidence are also provided in 2015b. The child had been exposed to neglect at a young age and is described as a 'vulnerable child who has had an extremely difficult start in life and who needs stability, security and predictability'. The court accepts the expert's statement that legalising the child's de facto relationship with his foster parents through adoption would benefit his development. In the 2018 judgment, the argument is justified by referring to expert evaluations stating that the child is particularly vulnerable and has a special need for protection, with which his biological mother also agrees. In addition, the child is assessed by experts as having developmental disabilities, which together with the vulnerability makes a special case for a care situation that protects him from disturbances and insecurity. In the 2019 judgment, the child is described as a 'normal boy for his age'. Nevertheless, the boy's exposure to serious neglect as well as the fact that his siblings have received serious diagnoses are considered to be grounds for viewing him as a vulnerable boy with risks of delayed impacts of past neglect:

I assume [the child] has a strong need for tranquillity and stability as a result of his difficult background with a violent father and a mother who, despite her love, has not been able to provide him with the necessary care in his first two years of life. The fact that [the child] is now a wellfunctioning child does not change this.

RT.2015 S.1107, PARAS. 47-48

While the justifications provided for the pragmatic argument in themselves are considered reasonable in all four judgments, considerable criticism can be made of the 2015b judgment for not considering the established vulnerability argument when addressing questions concerning his future, such as the risk of future litigation (see argument 13) and for postponing the decision on adoption (see argument 8).

\subsubsection{Argument 13. Risk of Future Conflict}

In 2015a, the claim of risk of future conflict if adoption is not consented to is supported by the placement being characterised by conflicts throughout the child's life. Recurring disputes between the parents and the municipality are seen to disturb placement stability for the child, and adoption is considered appropriate to protect the vulnerable child from future conflicts. Being pragmatically founded, the argument is considered valid. In $2015 \mathrm{~b}$, the court 
concludes that there was no risk that the father would be the cause of any disturbances or conflict. The assessment of the risk of future disturbances to the child's placement is largely based on his statements in evidence and the court's evaluation of the father's moral character. There are some blind spots in the reasoning. The child's perspective is basically absent from the risk assessment. Furthermore, while contact visits are terminated at the point of the judgment to safeguard the child from negative reactions, the father nonetheless expresses an expectation of future contact:

Nor is there any reason to assume that [the father] otherwise intends to oppose the placement or the access arrangements. This is enforced by [the father's] written statement before the Supreme Court, reading:

'Although I wish, of all my heart, that [the child] could live with me, I have accepted the placement in foster care with access rights sometime in the future. But I have not accepted adoption'

RT. 2015: 1107, PARA.51

The court could be criticised for not addressing this part of the statement when assessing the possibility of future litigation and disturbance to the placement. In the 2018 judgment, the justification for excluding the possibility of future legal disputes was grounded in a concern for the child's sense of safety and belonging. By deferring to the statements from the appointed expert, the court finds that the child should be protected from future litigation as it is considered to pose a risk of harm, partly as he would himself become more involved in the process through his right to be heard. The expert asserts that litigation and questions about access may cause emotional distress to this vulnerable child and have an unsettling effect on his feelings of safety and belonging. The argument is clearly anchored in the child's perspective and valid as a pragmatic claim. In the 2019 judgment, the court argues that adoption is a way of protecting the child from disturbances in his daily life. They mention the cws visits, which appear to upset him, and argue that there is a risk of future litigation and conflict that is also likely to affect the child. This argument is considered reasonably justified, although with the reservation that it is not obvious what substantiates the claim that visits from the cws upset him.

\subsubsection{Argument 14. The Child Wants to be Adopted}

The only judgment where the child's views are incorporated is the 2019 judgment. In other words, the children are not given the opportunity to voice their opinion in any of the three preceding judgments. In 2019, the child is given the opportunity to express his opinion in accordance with the law (CWA 
Section 6-3) and is heard by the court-appointed expert, who conveyed his thoughts and wishes to the court. To the expert, the child expressed the wish to be adopted and to receive the same surname as the rest of the family. The argument is given weight by the court, and it adheres to norms of justice and respect for children's rights. It is adequately justified by reference to the child's own wish and that he is considered able to understand what it means.

\subsection{Time}

One argument is connected to the time dimension. The argument is grounded in both a pragmatic and ethical discourse.

\subsubsection{Argument 15. Timing is Correct}

In the 2018 decision, the court claims that it is irrelevant to the decision about adoption to wait for further investigation of the child's health status, as this will remain unchanged even with knowledge of the causes of the boy's problems. The fact that he is soon to start school is also seen as a reason that adoption would be beneficial for the child at that time. A blind spot in the court's justification is that the potential implications of adoption for future support from the cws are not considered. In the 2019 decision, the argument is reasoned merely in a short paragraph stating that:

The father has argued that it is too early to break the biological bonds now. I do not agree with this. [The child] is six and a half years old and for him to get the full benefit of the adoption, it should take place now.

HR-2019-1266-A, PARA.109

The reason for this is not explicitly stated. Considering the overall context of the argument, and given the descriptions of his circumstances, such as his vulnerability and that he is unsettled by visits from the cws, it is possible to make more sense of the argument. Although not particularly grave, there are shortcomings in the pragmatic reasoning of both arguments. Ethical considerations, such as values concerning the particularity and temporality of childhood, are discussed in 2018 and to a certain extent in the 2019 judgment.

Discussion

This analysis has studied all the Supreme Court's judgments on adoption from care from 2015 through 2019, with the objective of mapping the court's reasoning concerning its best interests decisions and evaluating the extent to which they can be considered rational. The analysis revealed that the arguments are 
often of a pragmatic nature and are guided by norms of stability for the child, the value of (mainly) vertical and legal biological relationships, and vulnerability. Furthermore, the development in the delivery of rational, well-reasoned and thorough judgments is positive. The same can be said in regards to assuming and exploring the perspective of the child. The latest judgments - in particular, the 2018 judgment - not only include more arguments but also appear overall to be justified more strongly and rationally. The evaluation of the arguments nonetheless showed weaknesses in terms of rational reasoning in all four judgments, with concerns arising about ambiguity, lack of reasoning, coherence failure to meet the evaluation standards for argumentation, and exclusion of parties and relevant arguments. Some of the weak spots identified in the four cases are significantly more important than others. These include failing to involve the child or to assess the risk and the value of social and biological relationships from the child's perspective. This applies particularly to 2015 b, where several significant deficits are identified in the court's argumentation, which allows for subjectivity. While one cannot claim that the decision was erroneous, the rationality of the decision is compromised by the lack of attention to ambiguous or inconsequential elements of the argumentation and weak justification of arguments that are given decisive weight. I will discuss these matters below.

\subsection{Lack of Child's Perspective and the Absence of the Child's Own Voice}

According to Norwegian law, child participation should have a decisive position in best interests decisions (Skivenes and Sørsdal, 2018), and a prerequisite for the rationality of a decision is that the parties are included and freely heard. Nevertheless, the child is not heard in any of the first three judgments. Owing to the established special needs of the child in the 2018 judgment, this criticism applies mainly to the two judgments in 2015. That said, vulnerability should not be a reason for a default exclusion of his opinion (see, e.g., Archard and Skivenes, 2010). General Comment No. 14 (2013), point 54, relating to Article 12 of the CRC, underlines the point about respecting children's access to influence the determination of their best interests, regardless of their situation:

The fact that the child is very young or in a vulnerable situation (e.g. has a disability, belongs to a minority group, is a migrant, etc.) does not deprive him or her of the right to express his or her views, nor reduces the weight given to the child's views in determining his or her best interests.

The four children are all close in age, yet none meets the age threshold of seven years that legally obliges the court to hear the child under Norwegian law. The law, nonetheless, obliges decision makers to hear younger children who are 
capable of forming their own opinions (CWA, 1992 section 6-3; Adoption Act, 2017 section 9; Grunnloven, 2014 Article 104(1)). Therefore, one should expect to find deliberation of the children's capabilities to understand why they chose not to include their opinions and wishes in the judgments. The child's right to be heard is fundamental in adoption proceedings and has substantial, procedural and symbolic value (Fenton-Glynn, 2013). Nevertheless, the failure to incorporate the child's views and/or to provide independent representation in adoption cases is a recurring objection to both the Supreme Courts' (Skivenes, 2010; Sandberg, 2016) and the ECtHR's decision-making practices (Breen, Krutzinna, Luhamaa and Skivenes, 2020). Our findings highlight the need for continued and strengthened action to secure children's rights to participation.

\subsection{Guiding Norms of Stability in Care, Biology and Vulnerability}

The systematisation of the arguments into justificatory themes reveals that the court has a particular way of reasoning its decisions, and despite some variation in what arguments are considered and how they are constructed and weighted, there are some key tendencies in the court's reasoning.

First, compared with ethical discourses, there is an excess of arguments relating to pragmatic discourse. For a best interests decision to be considered rational and acceptable (Piper, 2000), the necessity to deliberate upon the normative good for a child in the given context is fundamental. If nothing else, these findings are a reminder for the Supreme Court to pay due attention to the values underlying considerations of the best interests of the child.

Second, all judgments are characterised by attention to claims relating to the right to family life and the de facto or biological relations between the child and his/her parent(s). This finding mirrors the tension in modern child welfare law between family preservation and partnership with permanence planning for children in alternative care (Parkinson, 2003). This implies that attention is given to continuity in the child's care situation as reflected in the stability principle under Norwegian law while also showing that the biological presumption - stemming from the "biological principle" in Norwegian child welfare law (Skivenes, 2002; 2010) - holds a significant position in the Supreme Court's decision-making. For the stability principle, the recognition and protection of the child's de facto family by the state correspond to the tendencies observed in the development of ECtHR case law (Breen, Krutzinna, Luhamaa and Skivenes, 2020) and state policy on adoption (Tefre, 2020). I find that the biological presumption appears in what Skivenes (2002) characterises as a "weak version", where the biological relationship has a value in itself, through discussions about contact, and what is termed a "legal version", where biology is interpreted and valued as legal bonds that maintain the legal ties. The 
court's attention to biological relations pertains mainly to the bonds between children and parents; although biological sibling relationships appear to be gaining more attention in the later decisions, ${ }^{12}$ the general lack of consideration given to biological sibling relationships or to social sibling relationships in $2015 \mathrm{~b}$, or attention to the children's own perspectives on valuable relationships, is troubling. On several occasions, children with experience of the child welfare system have problematised the lack of attention to sibling relationships in child welfare decisions (Landsforeningen for barnevernsbarn, 2012; Barnevernproffene, 2019), and research shows that both social and biological siblings have significance for the sense of belonging and identity of children in care (Angel, 2014). ${ }^{13}$ If decisions are to be legitimate and made from a child's perspective, the lack of attention to sibling relationships is thus highly problematic.

Third, the best interests of the child and the norm of particularly weighty reasons for adoption seem to be conditioned by assessments of the child's vulnerability and specific needs for stability and tranquillity. Apart from the $2015 \mathrm{~b}$ judgment, where the vulnerability argument is curiously not given weight or significant attention in the court's balancing act, the children's established vulnerability is considered significant in the decision. As both an independent argument and a variable for determining the relative strength of other arguments, such as the risk of conflict, one could speculate that emphasising vulnerability is an intentional move to make the essentially paternalistic intervention more acceptable, given the state's role as parens patriae. Children are vulnerable by the mere fact that they are children, and this factor should be taken into consideration when assessing and determining the child's best interests (Committee of the Rights of the Child, 2013). Yet caution should be exercised so that arguments of vulnerability are not used as a lever, and claims of vulnerability are not rationally considered, in terms of applicability, validity and the weight that they are given from the perspective of the case as a whole. Research has shown that adoption can be beneficial for children in long-term foster care placements (c.f., Hjern, Vinnerljung and Brännström, 2019; Christoffersen, 2012). Therefore, it is also ethically questionable whether only children proven to be vulnerable beyond what can be expected from a child in foster care are considered eligible for adoption. Moreover, it is open to question whether vulnerability should outweigh other individual traits and features of a decision, such as the child's opinion.

In 2018 and 2019, the biological parents refer to the child's relationships with siblings in their statements.

13 For an overview of relevant research, see Jones (2016). 
The analysis highlights the complexity of best interests assessments. The arguments provide varying degrees of justification and are of variable quality. The court's discretion is applied differently in terms of which arguments are included, the amount and type of evidence required, and how considerations are weighted and balanced against each other. Although we cannot dismiss the individuality of circumstances in each case, inconsistencies are problematic in terms of providing clarity of the law. ${ }^{14}$ Several objections of varying seriousness have been raised concerning the rationality of the Supreme Court's judgments on adoption in these past years. A major lesson for the courts must be to take children's right to participation seriously. Leaving children's voices out of the decision is not in line with the CRC, Norwegian law, or the current theoretical outlook on the best interests of the child. Neither the decisions nor the decision-making process can be conceived as legitimate and democratic as long these issues are unresolved.

\section{Acknowledgments}

This study has received funding from the Research Council of Norway under the Independent Projects - Humanities and Social Science program (grant no. 262773). My utmost gratitude to my supervisor Professor Marit Skivenes for all her invaluable support and feedback. Many thanks also to Professor AnneMette Magnussen for commenting on a draft for this article and to my colleagues at the Centre for Research on Discretion and Paternalism (UIB).

\section{References}

Adoption Act, Act of 16 June 2017 No. 48 relating to adoption (2017).

Alexy, R., A Theory of Legal Argumentation (Oxford: Clarendon Press, 1989).

Angel, В.Ø., "Foster Children's Sense of Sibling Belonging: The Significance of Biological and Social Ties", Sage Open 2014 (4), 1-10.

Appl. No. 17383/9o, Johansen v. Norway (1996), European Court of Human Rights.

Archard, D. and Skivenes, M., "Deciding best interests: general principles and the cases of Norway and the UK", Journal of Children's Services 2010 (5), 43-54.

14 See, e.g., Helland and Skivenes (2019) on how first instance judges find it challenging to interpret the signals from the Norwegian Supreme Court in matters of adoption. 
Bårdsen, A.,"De nordiske høyesterettene som prejudikatdomstoler - et perspektiv fra Norges Høyesterett," Lov og Rett 2016 (55(05)), 259-82.

Barnevernproffene i Forandringsfabrikken, Høringsinnspill til 2016 NOU 2016:16 Ny barnevernlov - Sikring av barnets rett til omsorg og beskyttelse, 2019.

Bendiksen L.R.L., Barn i langvarige fosterhjemsplasseringer-foreldreansvarog adopsjon (Bergen: Fagbokforlaget, 2008).

Breen, C., Krutzinna, J., Luhamaa, K. and Skivenes, M., "Family life for children in state care. An analysis of the European Court of Human Rights' reasoning on adoption without consent", The InternationalJournal of Children's Rights 2020 (28(4)), 715-747.

Child Welfare Act, The Act of 17 July 1992 No. 100 Relating to Child Welfare Services (1992).

Christoffersen, M.N., "A Study of Adopted Children, Their Environment, and Development: A Systematic Review", Adoption Quarterly 2012 (15(3)), 220-237.

Committee of the Rights of the Child, General Comment No. 14 2013, The Right of the Child to Have His or Her Best Interest Takes as a Primary Consideration (Art.3, Para.1) $\mathrm{CRC} / \mathrm{C} / \mathrm{GC} / 14$.

Coffey AJ, Atkinson P., Making Sense of Qualitative Data: Complementary Research Strategies (Thousand Oaks: SAGE Publications, Inc, 1996)

Council of Europe, European Convention for the Protection of Human Rights and Fundamental Freedoms, 1950.

Dworkin, R., "Judicial Discretion", The Journal of Philosophy 1963 (6o(21)), 624-638.

Eckhoff, T. and Helgesen, J.E., Rettskildelcere (Oslo: Tano Aschehoug, 1997).

Elster, J., Solomonic Judgments: Studies in the Limitations of Rationality (Cambridge: Cambridge University Press 1989).

Eriksen, E.O. and Weigård, J., Kommunikativ handling og deliberativt demokrati:Jürgen Habermas' teori om politikk og samfunn (Bergen: Fagbokforlaget, 1999).

Fenton-Glynn, C., "The child's voice in adoption proceedings: A European perspective”, International Journal of Children's Rights 2013 (21), 590-615.

Feteris, E.T., Fundamentals of Legal Argumentation: A Survey of Theories on the Justification of Judicial Decisions (Dodrecht: Kluwer Academic Publishers, 2017).

Forst, R.,"The Justification of Basic Rights: A Discourse-Theoretical Approach", Netherlands Journal of Legal Philosophy 2016 (45(3)), 7-28.

Grendstad, G., Shaffer, W.R. - Waltenburg, E.N., "Revealed Preferences of Norwegian Supreme Court Justices", Tidsskrift for rettsvitenskap 2010 (123), 73-101.

Grendstad, G., Shaffer, W.R., Sunde, J.Ø., and Waltenburg E.N., Proactive and Powerful: Law Clerks and the Institutionalization of the Norwegian Supreme Court (The Hague, the Netherlands: Eleven International Publishing, 2019).

Grunnloven [Norwegian Constitution], Kongeriket Norges Grunnlov [1814] 2014. Available at: https://lovdata.no/dokument/NLE/lov/1814-05-17. 
Habermas, J., Legitimation Crisis (Boston, MA: Beacon Press, 1975).

Habermas, J., Moral Consciousness and Communicative Action (Cambridge: Polity Press 1990).

Habermas, J., Between Facts and Norms (Cambridge, MA: MIT Press, 1996).

Haugli, T., "Kommentar til Høyesteretts kjennelse om hensynet til barnets beste og barns rett til å bli hørt», Juridika", 2020.

Helland, H.S. and Skivenes, M., Adopsjon som barneverntiltak. (Centre for Research on Discretion and Paternalism, University of Bergen, 2019).

Hirschl, R., "The Judicialization of Politics", in G.A Caldeira, D.R. Kelemen and K.E. Whittington (eds.), The Oxford Handbook of Law and Politics (Oxford: Oxford Univ. Press, 2009).

Hjern, A., Vinnerljung, B. and Brännström, L., "Outcomes in adulthood of adoption after long-term foster care: A sibling study", Developmental Child Welfare 2019 (1), $61-75$.

Huttunen, R. and Heikkinen, H., "Between facts and norms: action research in the light of Jürgen Habermas's theory of communicative action and discourse theory of justice", Curriculum Studies 1998 (6(3)), 307-322.

Jerkø, M., "Skal ikke «barnets beste» leses bokstavelig?," Lov og Rett 2018 (57 (o2), 112-28. Jones, C., "Sibling relationships in adoptive and fostering families: A review of the international research literature", Children in Society 2016 (30), 324-334.

Landsforeningen for barnevernsbarn, Høringsuttalelse til NOU 2012:5 Bedre beskyttelse av barns utvikling, 2012.

Lindbo, K., Barnevernloven, 7th edn. (Oslo: Gyldendal Akademiske, 2011).

Locke, J., Two Treatises on Government, P. Laslett (ed.) (Cambridge: Cambridge University Press [1698] 1988).

Kohm, L.M., "Tracing the Foundations of the Best Interests of the Child Standard in American Jurisprudence," Journal of Law \& Family Studies 2008 (10(2)), 337-376.

Magnussen, A.M., Domstolskapt rett. En institusjonell analyse av utviklingen av regelen om ulovfestet objektivt ansvar fra 1866 til 2003 (Ph.D. thesis, Bergen: The University of Bergen, 2006).

Mnookin, R.H. and Szwed. E., "The Best Interest Syndrome as the Allocation of Power in Child Care", in H. Geach and E. Szwed (eds.), Providing Civil Justice for the Child (London: Edward Arnold, 1983).

Riiber, T. and Syse, A. 2018. "Høyesteretts sirkelgang i Jakob (HR-2017-2015)", Tidsskrift for familierett, arverett og barnevernrettslige spørsmål 2018 (16 (o1)), 96-99.

Parkinson, P., "Child Protection, Permanency Planning and Children's Right to Family Life." International Journal of Law, Policy and the Family 2003 (17(2)), 147-72.

Piper, C., "Assumptions about Children's Best Interests", Journal of Social Welfare and Family Law 2000 (22), 261-76. 
Sandberg, K., "Barnets beste som rettighet", in I. Ikdahl and V. Blaker Strand (eds.), Rettigheter i velferdsstaten. Begreper, trender, teorier (Gyldendal Juridisk, 2016).

Sandberg, K., "Best Interests of the Child in the Norwegian Constitution," Children's Constitutional Rights in the Nordic Countries 2019 (5), 133-158.

Sandberg, K., "Storkammeravgjørelsene om barnevern," Tidsskrift for familierett, arverett og barnevernrettslige spørsmål 2020 (18(o2)), 148-59.

Schei, T., "Norges Høyesterett ved 20o-årsjubileet", G. Bergby, T. Schei, J.E.A. Skoghøy, and T.M. Øie (eds.), Lov Sannhet Rett: Norges Høyesterett 200 år (Bergen: Universitetsforlaget, 2015).

Sinclair, T., "Mad, bad or sad?: Ideology, distorted communication and child abuse prevention", Journal of Sociology 2005 (41(3)), 227-246.

Skivenes, M., Lovgivning og legitimitet - En evaluering av lov om barneverntjenester av 1992 i et deliberativt perspektiv (Ph.D. Thesis, Bergen: The University of Bergen, 2002).

Skivenes, M., "Judging the child's best interests: Rational reasoning or subjective presumptions?", Acta Sociologica 2010 (53(4)), 339-353.

Skivenes, M. and Sørsdal, L.M., "The Best Interest Principle across Child Protection Jurisdictions" in A. Falck-Eriksen and E. Backe-Hansen (eds.), Human Rights in Child Protection (London: Palgrave 2018).

Sørensen, C.B., "Langvarige fosterhjemsplasseringer og forholdsmessighetskravet i E MK art.8”, Lov og Rett 2020 (8), 59.

Tefre, Ø., "The Child's Best Interests and the Politics of Adoptions from Care in Norway", The International Journal of Children's Rights 2020 (28(2)), 288-321.

United Nations Office of the High Commissioner for Human Rights, Convention on the Rights of the Child, November 20, 1989. Retrieved from: http://www.ohchr.org/en/ professionalinterest/pages/crc.aspx. 